Back to Nature 
This page intentionally left blank 


\title{
Back to Nature
}

The Green and the Real in the Late Renaissance

\author{
Robert N. Watson
}

$\overline{\mathrm{PENN}}$

University of Pennsylvania Press

Philadelphia 
Copyright ( 1006 University of Pennsylvania Press

All rights reserved

Printed in the United States of America on acid-free paper

$\begin{array}{llllllllll}10 & 9 & 8 & 7 & 6 & 5 & 4 & 3 & 2 & 1\end{array}$

First paperback edition 2008

Published by

University of Pennsylvania Press

Philadelphia, Pennsylvania 19104-4112

Library of Congress Cataloging-in-Publication Data

Watson, Robert N.

Back to nature: the green and the real in the late Renaissance / Robert N. Watson.

p. $\mathrm{cm}$.

Includes bibliographical references ( $p$. ) and index.

ISBN-13: 978-0-8122-2022-3 (pbk. : alk. paper)

ISBN-10: 0-8122-2022-6 (pbk. : alk. paper)

1. English literature-Early modern, 1500-1700-History and criticism. 2. Nature in literature.

3. Pastoral literature, English-History and criticism. 4. Philosophy of nature in literature.

5. Human ecology in literature. 6. Renaissance-England. I. Title.

PR428.N39W39 2005

$820.9^{\prime} 36^{\prime} 09031-d c 22$

2005042431 
To my daughter,

Emma Cairns Watson 
This page intentionally left blank 